\title{
Performans Itik Tegal Betina dengan Sistem Pemeliharaan Intensif dan Semi Intensif di KTT Bulusari Kabupaten Pemalang
}

\author{
Female Tegal Duck Performance with Intensive and Semi Intensive Rearing System in KTT \\ Bulusari Pemalang
}

\author{
Agam Pradipta Adi, Dwi Sunarti, dan Rina Muryani \\ Fakultas Peternakan dan Pertanian Universitas Diponegoro \\ Tembalang 50275, Semarang. Indonesia \\ Corresponding e-mail: muryani.rina@live.undip.ac.id
}

\begin{abstract}
The aim of this study was to determine the differences of intensive and semi-intensive rearing systems on the performance of female Tegal ducks in feed composition and consumption of nutrients, feed conversion, and egg production. The study was conducted in April - May 2018 at Bulu farmer groups farm in Bulu Village, Pemalang District, Central Java. The material used in the study was 2265 female Tegal ducks from 13 farmers at the KTT Bulusari consisting of 6 semi-intensive breeders and 7 intensive rearing systems. Tegal duck were reared for 40 days. This research was a quantitative descriptive research that interpreted data from research samples, analyzed by the Mann-Whitney test. The results showed that the of feed and HDP of female Tegal ducks that were reared intensively was 7.09 and $57.57 \%$, while the ducks that were kept semi-intensive were 1.43 and $58.84 \%$. Semi-intensive rearing system is more profitable because less feed can produce optimal productivity.
\end{abstract}

Key words: Tegal duck, rearing system, intensive, semi intensive, egg production, and feed conversion

\begin{abstract}
ABSTRAK
Tujuan penelitian ini adalah untuk mengetahui perbedaan sistem pemeliharaan intensif dan semi intensif pada performans itik Tegal berupa komposisi dan konsumsi nutrien, konversi pakan dan produksi telur. Penelitian dilaksanakan pada bulan April - Mei 2018 di peternakan rakyat Desa Bulu, Kecamatan Petarukan, Kabupaten Pemalang, Jawa Tengah. Materi yang digunakan dalam penelitian yaitu 2265 ekor itik Tegal betina dari 13 peternak itik di KTT Bulusari yang terdiri dari 6 peternak dengan sistem pemeliharaan semi intensif dan 7 peternak dengan sistem pemeliharaan intensif. Itik Tegal dipelihara selama 40 hari. Penelitian ini merupakan jenis penelitian deskriptif kuantitatif yang menginterprestasikan suatu data dari sampel penelitian yang dianalisis dengan uji Mann-Whitney. Hasil penelitian menunjukkan bahwa konversi pakan dan HDP itik Tegal betina yang dipelihara secara intensif sebesar 7,09 dan 57,57\%, sedangkan itik yang dipelihara secara semi intensif adalah sebesar 1,43 dan $58,84 \%$. Sistem pemeliharaan semi intensif lebih menguntungkan karena lebih sedikit pakan dapat memproduksi secara optimal.
\end{abstract}

Kata kunci : itik Tegal, sistem pemeliharaan, intensif, semi intensif, produksi telur, dan konversi pakan

\section{PENDAHULUAN}

Itik merupakan ternak unggas yang dapat dimanfaatkan daging dan telurnya untuk dikonsumsi. Salah satu jenis itik yang dibudidayakan untuk dimanfaat telurnya adalah itik tegal. Itik tegal merupakan jenis atau bangsa itik asli Indonesia (lokal) yang berasal dari Tegal, Jawa tengah (Susanti dan Prasetyo, 2007). Sampai saat ini produktivitas itik petelur di Indonesia masih jauh dari harapan, sehingga kebutuhan akan telur sebagai protein hewani masih didominasi oleh telur ayam ras.

Salah satu penyebab rendahnya produktivitas telur itik, disebabkan karena sistem pemeliharaan yang berbeda-beda oleh masing-masing peternak. Sistem pemeliharaan pada ternak itik, pada dasarnya dibedakan menjadi tiga, yaitu sistem pemeliharaan ekstensif (umbaran), intensif (terkurung), dan semi intensif (dikandangkan di malam hari dan diumbar/digembalakan di siang hari). Ketiga sistem pemeliharaan 
tersebut mempunyai kelebihan dan kekurangan masing-masing yang berdampak pada produktivitas telur itik. Perbedaan sistem pemeliharaan berdampak pada produksi telur dan kualitas telur yang dihasilkan (Tumanggor et al., 2017).

Beberapa kajian sebelumnya tentang sistem pemeliharaan itik, ternyata memberikan hasil yang berbeda-beda, penelitian Kateren (2007) menunjukkan bahwa itik yang dipelihara dengan sistem intensif memiliki produktivitas yang lebih baik dibanding dengan itik yang dipelihara dengan sistem semi intensif. Produksi telur itik yang digembalakan hanya sekitar $26,9 \%$ - $41,3 \%$ setara dengan 98-151 butir/ekor/tahun, sedangkan pada sistem terkurung (intensif) produksi telur mencapai 55,6\% setara dengan 203 butir/ekor/tahun.

Penelitian Tumanggor et al. (2017) menunjukkan, bahwa itik yang dipelihara dengan sistem semi intensif dengan sesekali digembalakan di sawah memiliki produktivitas yang lebih baik jika dibandingkan dengan itik yang dipelihara dengan sistem intentif. Itik yang dipelihara dengan sistem semi intensif dan sesekali digembalakan di sawah akan mendapat nutrisi tambahan yang lebih baik daripada hanya diberikan nutrisi dari pakan ternah hasil pabrikan.

Temuan-temuan tersebut memberikan ketertarikan untuk melakukan penelitian lebih lanjut tentang sistem pemeliharaan itik secara intensif dan semi intensif. Pemalang, tepatnya di Desa Bulu Kecamatan Petarukan merupakan salah satu sentra peternakan itik tegal yang ada di Kabupaten Pemalang Jawa Tengah. Sebagian peternak memelihara itik dengan sistem intensif dan dan sebagian lagi semi intensif. Hal tersebut tentunya sejalan dengan apa yang akan menjadi kajian penelitian saat ini.

Penelitian ini bertujuan untuk mengetahui perbedaan sistem pemeliharaan intensif dan semi intensif terhadap produktivitas telur. Manfaat penelitian adalah memberikan informasi mengenai bagaimana pengaruh sistem pemeliharaan semi intensif dan intensif pada produksi telur, konsumsi pakan dan konversi pakan pada itik Tegal (Anas plantyhynchos javanicus).

\section{MATERI DAN METODE}

Materi yang digunakan dalam penelitian yaitu 2.265 ekor itik Tegal betina dari 13 peternak itik di KTT Desa Bulu Kecamatan Petarukan yang berasal dari 6 peternak dengan sistem pemeliharaan intensif dan 7 peternak dengan sistem pemeliharaan semi intensif. Itik Tegal dipelihara selama 40 hari.

Penelitian ini merupakan jenis penelitian deskriptif kuantitatif yang menginterprestasikan suatu data dari sampel penelitian yang dianalisis dengan metode statistik tertentu. Kegiatan yang dilakukan berupa tahap persiapan penelitian, berupa pendekatan personal dengan para peternak di Kecamatan Petarukan, Kabupaten Pemalang, Jawa Tengah yang digunakan untuk sistem pemeliharaan sistem semi intensif. Selanjutnya, daftar kuisioner disiapkan untuk mendapatkan data itik Tegal dari para peternak. Tahap berikutnya adalah tahap penelitian yaitu pengambilan data, dan tahap pengolahan data. Pakan peternak dianalisis di Laboratorium Ilmu Nutrisi dan Pakan Ternak, Universitas Diponegoro, untuk diketahui kandungan nutrisinya.

Parameter yang diukur dalam penelitian ini yaitu konsumsi pakan, produksi telur, konversi pakan. Pengukuran konsumsi pakan, dan produksi telur dilakukan setiap hari dari awal pemeliharaan sampai 40 hari dengan pengamatan langsung di lapangan dan observasi langsung ke peternak. Pengukuran parameter dilakukan dengan :

1. Konsumsi Pakan

Pemberian Pakan (g) - Sisa Pakan (g)

2. Produksi Telur dihitung dalam HDP (Hen Day Production)

$H D P=\frac{\text { Jumlah telur }}{\text { Jumlah itik }} \times 100 \%$

3. Konversi Pakan (FCR)

Konsumsi pakan $(\mathrm{g})$

Bobot telur (g) 
Data yang diperoleh kemudian dibandingkan rata-ratanya antar perlakuan dengan menggunakan uji Mann-Whitney dengan bantuan software SPSS (Statistical Package for Social Sciences).

\section{HASIL DAN PEMBAHASAN}

\section{Komposisi Pakan}

Komposisi pakan peternak intensif dan semi intensif di KTT Bulusari, Pemalang menggunakan bahan pakan yang sama untuk menyusun ransum itik Tegal yaitu ikan segar (ulam), bekatul, dan nasi kering (aking). Komposisi bahan pakan penyusun ransum dapat dilihat pada Gambar 1.

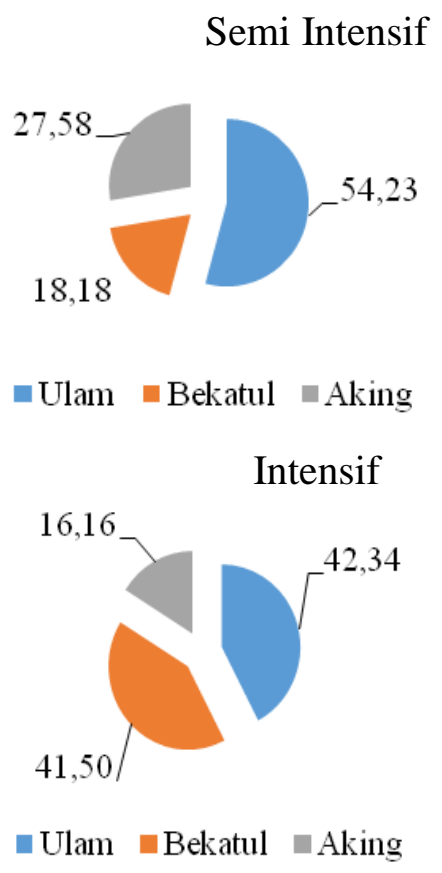

Hasil penelitian menunjukkan bahwa peternak semi intensif memberikan persentase ikan segar dan nasi kering (aking) lebih banyak dibanding peternak intensif, sedangkan peternak intensif memberikan bekatul dengan persentase lebih banyak. Perbedaan komposisi ransum tersebut menyebabkan kandungan nutrien dalam ransum berbeda. Kandungan energi metabolis, protein kasar, serat kasar, lemak kasar, kalsium, dan phosphor dalam ransum dapat dilihat pada Tabel 1.

Tabel 1. menunjukkan bahwa meskipun komposisi bekatul lebih banyak pada ransum itik intensif, tetapi ransum itik semi intensif mempunyai kandungan energi yang lebih tinggi. Pakan itik intensif dan semi intensif mempunyai kandungan energi sesuai dengan standar. Standar Nasional Indonesia (2000) menyebutkan bahwa kebutuhan energi itik fase layer adalah sebesar $2700 \mathrm{kkal}$. Standar energi metabolis yang dibutuhkan itik petelur, yakni minimal sebesar 2900 kkal (Sinurat, 2000). Pakan itik intensif dan semi intensif juga mempunyai kandungan protein yang sudah sesuai dengan standar. Sinurat (2000) menyatakan bahwa pakan itik petelur harus mempunyai PK sebesar $17-19 \%$.

Purba et al. (2015) menyatakan bahwa kebutuhan protein pada hakekatnya adalah kebutuhan asam amino, terutama asam amino esensial yang tidak dapat disintesis oleh tubuh itik sehingga harus

Gambar 1. Diagram komposisi ransum

Tabel 1. Perbandingan kadar nutrien ransum

\begin{tabular}{llrrrrrr}
\hline \multirow{2}{*}{ Kelompok } & \multirow{2}{*}{ Pakan } & \multicolumn{7}{c}{ Kadar } & nutrien \\
\cline { 3 - 8 } Intensif & & Kkal & PK & SK & LK & Ca & P \\
\hline & Ikan segar & 1392,2 & 11,88 & 1,78 & 0,86 & 1,296 & 0,69 \\
& Bekatul & 1157,8 & 4,20 & 7,23 & 0,76 & 0,008 & 0,28 \\
& Aking & 575,5 & 1,39 & 0,08 & 0,01 & 0,003 & 0,01 \\
\hline \multirow{3}{*}{ Semi intensif } & Total & 3125,5 & 17,47 & 9,09 & 1,63 & 1,307 & 0,98 \\
& Ikan segar & 1783,3 & 15,22 & 2,28 & 1,10 & 1,660 & 0,89 \\
& Bekatul & 507,4 & 1,84 & 3,17 & 0,33 & 0,004 & 0,12 \\
& Aking & 982,2 & 2,38 & 0,13 & 0,02 & 0,006 & 0,01 \\
\hline & Total & 3272,8 & 19,44 & 5,58 & 1,45 & 1,670 & 1,03 \\
\hline
\end{tabular}


terkandung dalam pakan. Fouad et al. (2018) menyatakan bahwa asam amino yang sangat dibutuhkan oleh itik petelur adalah metionin, lisin, treonin, dan arginin. Kandungan metionin, lisin, treonin, dan arginin dalam pakan dapat mempengaruhi produksi telur, bobot telur ,ukuran telur, dan kualitas cangkang telur pada itik. Kebutuhan asam amino itik baik yang dipelihara secara intensif dan semi intensif dapat dipenuhi karena ikan segar mempunyai kandungan asam amino yang cukup lengkap. Kadar asam amino pada ransum itik dapat dilihat pada Tabel 2.

Kadar asam amino yang terkandung dalam ikan segar yang diberikan oleh peternak diperkirakan sudah sesuai dengan standar. Fouad et al. (2018) menyatakan bahwa kadar metionin yang dibutuhkan itik petelur yaitu sebesar $0,41 \%$, lisin sebesar $0,80 \%$, treonin sebesar $0,57 \%$, dan arginin $1,46 \%$. Kebutuhan asam amino itik baik yang dipelihara secara intensif dan semi intensif dapat dipenuhi karena keduanya sama-sama menggunakan ikan segar. Talat dan Azmat (2006) menyatakan bahwa ikan segar dari pelelangan ikan (trash fish) yang biasa digunakan sebagai pakan mempunyai kandungan asam amino berupa arginin 3,0\%, histidin $1 \%$, lisin $2,4 \%$, fenilalanin $2,6 \%$, tyrosin $1,5 \%$, leusin $0,35 \%$, isoleusin $1,3 \%$, metionin $1,2 \%$, valin $0,2 \%$, glutamin $0,9 \%$, alanin $0,1 \%$, asparagin $0,41 \%$, dan treonin $1,5 \%$.

Tabel 2. Kadar asam amino ikan segar dalam ransum

\begin{tabular}{|c|c|c|c|c|c|}
\hline Kelompok & Bahan Pakan & Metionin* & Lisin* & Treonin* & Arginin* \\
\hline & & \multicolumn{4}{|c|}{ |------------------------ \% ------------------- } \\
\hline Intensif & Ikan segar & 0,508 & 1,016 & 0,635 & 1,270 \\
\hline Semi intensif & Ikan segar & 0,651 & 1,302 & 0,813 & 1,627 \\
\hline & Standar** & 0,410 & 0,800 & 0,570 & 1,460 \\
\hline
\end{tabular}

Kandungan lemak kasar (LK) ransum itik kedua kelompok masih kurang dari standar SNI (2000) yaitu 3,5\%. Kandungan LK berada dibawah standar dimungkinkan karena ransum kedua kelompok peternak hanya menggunakan tiga jenis bahan pakan saja, sedangkan sumber lemak ransum unggas pada umumnya berasal dari bahan pakan bungkil dan jagung yang banyak mengandung minyak. Semakin banyak atau bervariasis bahan pakan yang digunakan untuk menyusun ransum maka akan semakin lengkap nutrisinya. Afandi et al. (2006) menyatakan bahwa penyusunan ransum harus mempertimbangkan nutrisi yang terkandung dalam bahan pakan, pakan disusun atas dasar nilai kecukupan kebutuhan nutrisi. Ransum yang baik tersusun atas beberapa bahan pakan sumber energi, sumber protein, sumber vitamin dan mineral, serta mempertimbangkan kandungan lemak dan serat kasar agar nutrisinya seimbang. Lemak yang terdapat dalam pakan akan mempengaruhi bobot telur karena kuning telur sebagian besar tersusun atas lemak, selain itu lemak merupakan cadangan energi yang dapat disimpan dalam tubuh dan digunakan saat itik kekurangan pakan (Juliambarwati, 2012)

Kandungan $\mathrm{Ca}$ ransum kedua peternak adalah $1,30-1,67 \%$, sehingga sudah sesuai dengan standar Ca yang disitasi oleh Imawan et al. (2016) yang menyatakan bahwa kandungan $\mathrm{Ca}$ dalam ransum itik petelur yakni sebesar $0,88-1,75 \%$. Kandungan fosfor ransum kedua peternak adalah $0,98-1,03 \%$, sehingga sudah sesuai dengan standar fosfor yang dikemukan oleh SNI (2000) dan Sinurat (2000), yakni sebesar $0,6-1 \%$. Ketaren (2010) menyatakan bahwa unsur $\mathrm{Ca}$ dan $\mathrm{P}$ pada dasarnya digunakan untuk menunjang pembentukan cangkang pada telur. 


\section{Konsumsi Pakan}

Tabel 3. Konsumsi ransum

\begin{tabular}{|c|c|c|c|}
\hline Kelompok & Bahan Pakan & $\begin{array}{c}\text { Konsumsi } \\
\text { (g/ekor/hari) }\end{array}$ & $\begin{array}{c}\text { Persentase } \\
(\%)\end{array}$ \\
\hline \multirow{4}{*}{$\begin{array}{c}\text { Intensif } \\
\text { (Populasi 1060) }\end{array}$} & Ikan segar & 120,30 & 42,34 \\
\hline & Bekatul & 117,91 & 41,50 \\
\hline & Aking & 45,91 & 16,16 \\
\hline & Total & $284,13^{\mathrm{a}}$ & 100,00 \\
\hline \multirow{4}{*}{$\begin{array}{c}\text { Semi Intensif } \\
\text { (Populasi 1205) }\end{array}$} & Ikan segar & 31,35 & 54,23 \\
\hline & Bekatul & 10,51 & 18,18 \\
\hline & Aking & 15,94 & 27,58 \\
\hline & Total & $57,81^{b}$ & 100,00 \\
\hline
\end{tabular}

Itik Tegal petelur yang dipelihara secara semi intensif mengkonsumsi ransum dengan jumlah sedikit karena sebagian kebutuhan pakan itik dapat diperoleh saat digembalakan. Pada sistem pemeliharaan semi intensif, itik dilepas atau digembalakan pada siang hari untuk mencari pakan dan ternak itik dimasukkan kembali ke dalam kandang pada sore hari. Pemberian pakan pada itik semi intensif tidak terlalu banyak karena itik dapat mencari pakan sendiri saat digembalakan. Konsumsi ransum itik semi intensif melebihi standar, sedangkan konsumsi pakan itik semi intensif sebelum digembalakan masih dibawah standar. Sinurat (2000) menyatakan bahwa kebutuhan pakan itik petelur dewasa > 20 minggu membutuhkan pakan sebanyak $160-180$ g/ekor/hari. Perbedaan konsumsi ransum akan menyebabkan konsumsi nutrien juga berbeda. Konsumsi nutrien itik dapat dilihat pada Tabel 4.

Konsumsi nutrien itik petelur yang dipelihara secara intensif sudah terpenuhi, bahkan melebihi standar kecuali konsumsi LK, sedangkan pada itik semi intensif konsumsinya berada dibawah standar. Nugraha et al. (2012) menyatakan bahwa kebutuhan pakan itik Tegal petelur yaitu protein sebesar $26 \mathrm{~g} /$ ekor/hari, EM sebesar 390 kkal/ekor/hari, SK sebesar 16,8 g/ekor/hari, LK sebesar 7 g/ekor/hari, Ca sebesar 3,5 g/ekor/hari, dan $\mathrm{P}$ sebesar 1,4 g/ekor/hari. Konsumsi protein yang terlalu tinggi tidak efisien karena protein yang tidak tercerna hanyak terbuang. Sari dan Afrila (2014) menyatakan bahwa jika konsumsi protein ransum melebihi kebutuhan akan menyebabkan kerugian karena kelebihan protein tersebut tidak dicerna, melainkan akan dibuang lewat ekskreta.

Tabel 4. Konsumsi nutrien itik

\begin{tabular}{llrccccc}
\hline \multirow{2}{*}{ Kelompok } & \multirow{2}{*}{ Pakan } & \multirow{2}{*}{ EM $(\mathrm{Kkal})$} & \multicolumn{5}{c}{ Konsumsi Nutrien (g/ekor/hari) } \\
\cline { 4 - 8 } Intensif & Ikan segar & 395,56 & 33,76 & 5,05 & 2,44 & 3,681 & 1,97 \\
& Bekatul & 271,62 & 11,93 & 20,55 & 2,16 & 0,025 & 0,79 \\
& Aking & 163,48 & 3,96 & 0,22 & 0,03 & 0,010 & 0,02 \\
& Total & 830,66 & 49,65 & 25,82 & 4,63 & 3,691 & 2,78 \\
\hline \multirow{3}{*}{ Semi intensif } & & & & & & & \\
& Ikan segar & 103,08 & 8,80 & 1,31 & 0,63 & 0,959 & 0,51 \\
& Bekatul & 24,21 & 1,06 & 1,83 & 0,19 & 0,002 & 0,07 \\
& Aking & 41,09 & 0,99 & 0,06 & 0,01 & 0,002 & 0,01 \\
& Total & 168,38 & 10,85 & 3,23 & 0,84 & 0,963 & 0,59 \\
\hline
\end{tabular}


Konsumsi energi yang melebihi kebutuhan juga tidak baik untuk itik petelur karena kelebihan energi akan disimpan dalam bentuk lemak, apabila itik terlalu gemuk akan berpengaruh terhadap produktivitas telur. Itik yang dipelihara secara semi intensif mengkonsumsi nutrien lebih rendah dan dibawah standar, tetapi kebutuhan nutrien itik masih bisa terpenuhi karena saat digembalakan itik dapat mencari pakan sendiri. Hasil penelitian menunjukkan bahwa isi tembolok itik semi intensif berisi bahan pakan lain selain bahan pakan penyusun ransum. Bahan yang ditemukan di dalam tembolok itik antara lain gabah, keong, hijauan, dan bahan lainnya yang tidak diketahui.

Gabah merupakan biji padi yang masih utuh dan mempunyai kandungan energi yang tinggi, sedangkan keong merupakan pakan tambahan yang mempunyai kandungan protein tinggi pula. Sandhy (2000) menyatakan bahwa keong bisa dijadikan sebagai pakan tambahan itik yang kaya akan protein.

Tabel 5. Komposisi bahan pakan dalam tembolok itik semi intensif

\begin{tabular}{lc}
\hline Jenis Bahan Pakan & Persentase $(\%)$ \\
\hline Gabah & 75,81 \\
Keong & 16,85 \\
Hijauan & 3,23 \\
Bahan lain & 4,12 \\
\hline Jumlah & 100,00 \\
\hline
\end{tabular}

Konsumsi energi itik semi intensif yang kurang bisa tercukupi dengan mengkonsumsi gabah sehingga kebutuhan energi metabolisnya terpenuhi, sedangkan kebutuhan protein dan asam amino itik dapat dipenuhi dengan mengkonsumsi keong. Firdus dan Muchlisin (2005) menyatakan bahwa daging keong mengandung protein 50 - $60 \%$ dengan kandungan asam amino arginin $18,9 \%$, histidin $2,8 \%$, isoleusin $9,2 \%$, leusin $10 \%$, lisin $17,5 \%$, methionine $2 \%$, phenilalanin $7,6 \%$, threonin $8,8 \%$, triptofan $1,2 \%$, dan valin $8,7 \%$.

\section{Konversi Pakan}

Hasil penelitian menunjukkan bahwa nilai Feed Conversion Ratio (FCR) itik yang dipelihara secara semi intensif mempunyai angka lebih rendah dibandingkan itik intensif. Hal ini menunjukkan bahwa pakan yang diberikan oleh kelompok peternak intensif kurang efisien dibanding kelompok peternak semi intensif. Anggorodi (1985) mengatakan, bahwa penggunaan ransum semakin efisien apabila nilai FCR-nya semakin kecil, dan dikatakan buruk jika nilai FCR mencapai 3,2-5.

Ransum yang diberikan kelompok peternak intensif kurang efisien karena jumlah pemberian ransum terlalu banyak. Hal ini terjadi karena kelompok peternak intensif beranggapan pemberian pakan dalam jumlah besar akan lebih baik, sebab itik yang dipelihara secara intensif tidak mendapat pakan tambahan dari luar. Pakan yang diberikan peternak semi intensif dinilai lebih efisien, nilainya yang lebih kecil dikarenakan pemberian ransum hanya sedikit karena itik dapat mencari pakan tambahan saat digembalakan. Siregar et al., (1980) menyatakan bahwa tingkat konversi ransum sangat tergantung dengan konsumsi ransum yang dihabiskan pada waktu tertentu, semakin baik mutu ransum maka angka konversi semakin kecil.

Tabel 6. Konversi ransum masing - masing kelompok peternak

\begin{tabular}{ccc}
\hline \multirow{2}{*}{ Kelompok Peternak } & \multicolumn{2}{c}{ Feed Conversion Ratio $(\mathrm{FCR})$} \\
\cline { 2 - 3 } & Kisaran & Rata-rata \\
\hline Intensif & $6,12-7,87$ & $7,09^{\mathrm{a}}$ \\
Semi Intensif & $1,28-1,66$ & $1,43^{\mathrm{b}}$ \\
\hline
\end{tabular}


Baik atau tidaknya mutu ransum ditentukan oleh keseimbangan zat-zat makanan yang terkandung dalam ransum, artinya konsumsi ransum akan meningkat jika ransum yang diberikan mengandung nilai energi yang rendah, begitu pula sebaliknya.

Hasil penelitian menunjukkan bahwa sistem pemeliharaan intensif memiliki kelemahan, seperti pemberian pakan itik yang tergantung sepenuhnya oleh peternak, namun dari segi pemeliharaan, lebih sederhana, dan dari segi waktu lebih efisien. Hal tersebut berbeda dengan pemeliharaan semi intensif yang membutuhkan waktu lebih banyak dalam pemeliharaan itik. Jika dilihat dari jumlah pakan yang diberikan lebih sedikit karena itik yang digembalakan akan mendapat pakan tambahan dari sawah. Setioko (2000) menyatakan, bahwa keuntungan yang didapatkan peternak jika itik digembalakan di sawah, yaitu peternak tidak perlu membelikan pakan secara keseluruhan, sebab sebagian pakannya dapat diperoleh dari sawah, disisi lain, kerugiannya adalah bahwa sewaktu-waktu itik dapat mengkonsumsi bahan pakan yang terkontaminasi pestisida, dan bangkai tikus atau ular yang mengandung racun sehingga dapat mengakibatkan kematian pada itik, belum lagi resiko kehilangan itik sewaktu digembalakan.

\section{Produksi Telur}

Tabel 7. Produksi telur itik

\begin{tabular}{llc}
\hline No. & $\begin{array}{c}\text { Kelompok } \\
\text { Peternak }\end{array}$ & $\begin{array}{c}\text { Nilai } \\
\text { (Hen Day Production) }\end{array}$ \\
\hline 1. & Intensif & $57,57 \%^{\mathrm{a}}$ \\
2. & Semi Intensif & $58,84 \%^{\mathrm{a}}$ \\
\hline
\end{tabular}

Hasil penelitian menunjukkan bahwa tidak ada perbedaan produksi telur itik yang dipelihara dengan sistem pemeliharaan intensif dan semi intensif. Produksi telur itik pada kedua kelompok sistem pemeliharaan sudah sesuai dengan standar. Hal ini sesuai dengan pendapat Ketaren (2007) yang menyatakan bahwa produksi telur itik yaitu sebesar 55,6\% setara dengan 203 butir/ekor/tahun.

Produksi telur itik yang dipelihara secara intensif dan semi intensif di KTT Bulusari Pemalang tidak berbeda, hal ini menunjukkan bahwa kebutuhan nutrien itik baik itu pada kelompok intensif dan semi intensif sudah terpenuhi. Itik semi intensif diberi pakan dengan jumlah lebih rendah dibandingkan itik intensif, tetapi terbukti tidak mempengaruhi produksi telur. Hal ini menandakan bahwa kebutuhan itik semi intensif terpenuhi karena pakan tambahan berupa gabah dan keong yang didapatkan di sawah. Tumanggor et al. (2017) menyatakan bahwa itik yang dipelihara dengan sistem semi intensif dengan sesekali digembalakan di sawah memiliki produktivitas yang baik karena itik yang dipelihara dengan sistem semi intensif dan sesekali digembalakan di sawah akan mendapat nutrisi tambahan yang lebih baik daripada hanya diberikan nutrisi dari pakan ternah hasil pabrikan.

\section{KESIMPULAN}

Hasil penelitian menunjukkan bahwa produksi telur itik Tegal yang dipelihara secara intensif tidak berbeda dengan itik yang dipelihara secara semi intensif, meskipun kedua kelompok tersebut mempunyai kualitas dan kuantitas pakan yang berbeda. Sistem pemeliharaan semi intensif lebih menguntungkan karena dengan pakan yang lebih sedikit bisa menghasilkan produktivitas yang optimal..

\section{SARAN}

Perlu dilakukan evaluasi terkait dengan jumlah pakan yang diberikan oleh kelompok peternak intensif, pemberian pakan sudah melebihi kebutuhan nutrien itik sehingga tidak efisien.

\section{DAFTAR PUSTAKA}

Afandi, R. B. Hartono, Irfan, dan H. Djunaidi. 2006. Karakteristik penggunaan dua jenis pakan terhadap performa produksi ayam ras petelur di 
Kabupaten Blitar Jawa Timur. Jurnal Ilmu Ternak dan Veteriner 14 (2) : 103-105.

Anggorodi, R. 1985. Ilmu Makanan Ternak Umum. PT. Gramedia, Jakarta.

Budiharjo, K., D. Sumarjono, M. Handayani, dan G. Siwi. 2009. Studi potensi ekonomi usaha ternak itik di kabupaten Tegal. Prosiding Seminar Kebangkitan Nasional 20 Mei 2009: 572-580.

Firdus, dan Z.A. Muchlisin. 2005. Pemanfaatan keong mas (Pomacea canaliculata) sebagai pakan alternatif dalam budidaya ikan kerapu lumpur. J. Enviro. 5 (1) ;64-66.

Fouad, A. M., D. Ruan, S. Wang, W. Chen, W. Xia, dan C. Zheng. 2018. Nutritional requirements of meat type and egg type duck. Journal of Animal Science and Biotechnologi. 9 (1) : 111.

Imawan, M. R., R. Sutrisna, dan T. Kartini. 2016. Pengaruh ransum dengan kadar protein kasar berbeda terhadap pertumbuhan itik betina Mojosari. Jurnal Ilmiah Peternakan Terpadu 4 (4) : 300-306.

Juliambarwati, M. 2012. Pengaruh Penggunaan Tepung Limbah Udang dalam Ransum Terhadap Kualitas Telur Itik. Fakultas Peternakan Universitas Sebelas Maret, Surakarta (Skripsi).

Ketaren, P. 2007. Peran Itik sebagai Penghasil Telur dan Daging Nasional. Balai Penelitian Ternak, Bogor.

Ketaren, P. 2010. Kebutuhan Gizi Ternak Unggas di Indonesia. Balai Penelitian Ternak, Bogor.

Nugraha, D., U. Atmomarsono dan L. D. Mahfudz. 2012. Pengaruh penambahan eceng gondok (Eichornia crassipes) fermentasi dalam ransum terhadap produksi telur itik Tegal. Animal Agricultural Journal. 1 (1) : 75-85.

Prasetyo, H., dan Ketaren, P. 2005. Interaksi antara bangsa itik dan kualitas ransum pada produksi dan kualitas telur itik Lokal. Prosiding Seminar Nasional Teknologi Peternakan dan Veteriner. Balai Penelitian Ternak, Bogor.

Purba, M, T. Haryati, dan A. P. Sinurat. 2015. Performa Itik Pedaging EPMp dengan Pemberian Pakan yang mengandung Berbagai Level Lisin selama Periode Starter. Balai Penelitian Ternak, Bogor.

Ranto. 2005. Panduan Lengkap Beternak Itik. Agromedia Pustaka, Jakarta.

Rasyaf, M. 2002. Beternak Itik. Edisi ke-16. Kanisius. Yogyakarta.

Sandhy, S. W. 2000. Beternak Itik Tanpa Air. Penebar Swadaya. Jakarta.

Suharno, Bambang, dan Toni, S. 2002. Beternak Itik Petelur di Kandang Baterai. Penebar Swadaya, Jakarta.

Sari, E., dan A. Afrila. 2014. Efek enzim papain pada berbagai pakan kandungan protein berbeda terhadap produksi dan kecernaan ayam kampung. Buana Sains. 14 (1) : 85 94.

Setioko, A, R., S. Iskandar., Y, C, Raharjo., T, D, Soedjana., T, Murtisari., M, Purba., S, E., N, Sunandar dan D, Sarosa. 2000. Model usaha ternak itik dalam sistem pertanian IP 300. Jurnal Ilmu Ternak dan Veteriner. 5(1) : 3845 .

Sinurat, A. P. 2000. Penyusunan Ransum Ayam Buras dan Itik. Pelatihan Proyek Pengembangan Agribisnis Peternakan. Dinas Peternakan DKI Jakarta, Jakarta. 
Siregar, A.P. M. Sabroni, dan Suroprawiro. 1980. Teknik Beternak Ayam Pedaging di Indonesia. Margie Group, Jakarta.

Standar Nasional Indonesia. 2000. Pakan Itik Petelur. Badan Standarisasi Nasional Indonesia No. 3910. Jakarta.

Srigandono, B. 1997. Produksi Unggas Air. Gadjah Mada University Press, Yogyakarta.

Subiharta, M. D. Yuwono, dan P. Sudrajat. 2013. Karakteristik Itik Tegal (Anas plantyhyncos javanicus) sebagai Itik petelur unggulan lokal jawa tengah dan upaya peningkatan produksinya. Seminar Nasional: Menggagas Kebangkitan Komoditas Unggulan Lokal Pertanian dan Kelautan. Fakultas Pertanian Universitas Trunojoyo, Madura.

Suharno, B. dan K. Amri. 2003. Beternak Itik secara Intensif. Cetakan $\mathrm{Ke}-8$. Penebar Swadaya, Jakarta.
Susanti, T. dan L.H. Prasetyo. 2007. Panduan Karakterisasi Ternak Itik. Pusat Penelitian dan Pengembangan Peternakan, Bogor.

Swacita, I. B. N dan S. Cipta. 2011. Pengaruh sistem peternakan dan lama penyimpanan terhadap kualitas telur itik. Buletin Veteriner Udayana. Fakultas Kedokteran Hewan Universitas Udayana. 3 (2) : 91-98.

Talat, R., and R. Azmat. 2006. Nutritive evaluation of edible trash fish: II use of trash protein in cereal food diet. Journal of Zoological Research 2 (2) : $110-115$.

Tumanggor, B. G., D. M. Suci, dan S. Suharti. 2017. Kajian pemberian pakan pada itik dengan sistem pemeliharaan intensif dan semi intensif di peternakan rakyat. Buletin Makanan Ternak. 104 (1) : 21-29. 